\title{
Beware States Piercing Holes into Citizenship
}

\author{
Matthew J. Gibney
}

I find a great deal to agree with in Audrey Macklin's trenchant and wideranging argument against denationalisation power's recent revival in Western countries. Yet I also understand where her critics are, somewhat abrasively, coming from. It is of course possible to imagine carefully fashioned cases where denationalisation seems a morally appropriate response as long as a range of guarantees are met (for example, when an individual represents a clear threat to the state, where there are no doubts about his guilt or intentions, and where he could be stripped of citizenship without being made stateless.) However, while this realisation might help us identify the terms on which the denationalisation of a particular individual is permissible, it tells us little about the broader consequences of piercing the norm of unconditional citizenship for punitive reasons. ${ }^{1}$ I think that once we are realistic about the political dangers of conceding to the state powers to withdraw citizenship, we're brought back to a position compatible with Audrey Macklin's ban on denationalisation.

Before explaining why I think an absolute bar might be justified let make a couple of comments on the previous discussion. The first of these is on what one might call the statelessness constraint. All of the critics of Audrey Macklin's position start (with the possible exception of Christian Joppke) by accepting that individuals, even those who commit terrorist acts, should not be made stateless. This constraint against statelessness is not simply a matter of international or domestic law; it is also a normative constraint that stems from basic liberal commitments. The problem with statelessness is that it leaves individuals subject to state power without citizenship's basic protections against that power, including security of residence, political rights, and potentially a host of other entitlements. If we accept this normative rationale for guarding against statelessness, as I think we should, we will also want to

My focus in this short piece is exclusively on the punitive withdrawal of citizenship. There are, of course, other reasons why states have sought to 'pierce' citizenship, for example, to address fraudulent acquisition of citizenship or to prevent dual nationality. 
ensure that those denationalised are not made de facto stateless, that is, forced to rely on a state that is unable and unwilling to protect them or otherwise to deliver the fundamental rights citizenship (or nationality) is supposed to guarantee. ${ }^{2}$

Yet taking this additional constraint seriously is going to be very consequential. The secondary citizenships of the individuals Western states most want to strip of citizenship tend to be those of countries with dubious human rights records and histories of civil war and conflict (Somalia, Iraq, Eritrea, Sudan, to name a few). ${ }^{3}$ If de facto statelessness is a bar, most of the prime targets are going to be out of denationalisation's reach. Of course, de facto statelessness does not establish a case for an absolute rejection of the state's power to denationalise. But it does show why the power's scope may be very narrow indeed, at least for liberals.

Second, I find myself attracted to the position of Rainer Bauböck that one reason denationalisation is unacceptable is because it involves states 'passing the buck' of their own responsibilities on to other states, a point that adds a different dimension to Audrey Macklin's claim that citizenship is, in important respects, not fungible. This view that banishment is unfair to other states is a very old one. None other than Voltaire argued against the practice of banishment on the grounds that it involves throwing into our neighbour's field the stones that incommode us in our own.

Powerful as it is, however, the consideration that there's something wrong with denationalising 'home grown' terrorists, wouldn't mean that denationalisation was always inappropriate. States might still claim the moral right to denationalise individuals who had held citizenship only for a short period of time or had spent most of their lives living in the other

2 Cf. Barry, C. \& L. Ferracioli (2013), 'Withdrawing Citizenship', paper delivered at the Australian National University, Canberra, 16 July 2013. I accept that specifying exactly what is included in the concept of 'de facto statelessness' is not necessarily clear, as is the relationship between de facto statelessness and simple human rights abuses. A good starting point for further consideration of this issue is Sawyer, C. \& B. K. Blitz (eds.) (2011), Statelessness in the European Union: displaced, undocumented, unwanted. Cambridge: Cambridge University Press.

3 Note, for example, the second nationalities of the denationalised individuals that the Bureau of Investigative Journalism has been able to track, available at https://www.thebureauinvestigates.com/stories/2014-12-10/ what-do-we-know-about-citizenship-stripping. 
country in which they held citizenship. Germany certainly should not have posthumously denationalised Hitler. But Hitler was the leader of the German state and celebrated in this role by a significant proportion of the German people during the 1930s and 1940s. Putting aside the question of what should be done posthumously, some citizens have a much more tenuous, even a merely nominal, relationship to the state. Not all are even grown at home.

These considerations help to clarify some of the constraints necessary for a liberal denationalisation power. Even from the short discussion here, we can identify plenty of others. Peter Schuck suggests that an individual's threat to the state needs to be 'rigorously proven' and Kay Hailbronner argues that citizenship deprivation must be 'subject to proportionality'. It's clear that satisfying all of these different requirements will make the construction of denationalisation law consistent with liberal principles a Herculean task. However, where I part company with the denationalisers is not so much over whether it's possible to identify a liberal starting point for the practice. ${ }^{4}$ Rather, my concern is over the illiberal direction denationalisation seems likely to take once it returns to the political repertoire. Here my position has been greatly influenced by the recent experience of the UK. ${ }^{5}$

When denationalisation was first revived after over thirty years of desuetude by the Blair government in 2002, the power was tightly constrained: the definition incorporated was taken from the European Convention on Nationality, only dual nationals were targeted, and an automatic judicial appeal was to follow any decision by the Home Secretary. The government promised to use the power rarely. This modest beginning for denationalisation did not last. After the London bombings in July 2005, a new act passed by the Blair government in 2006 lowered the standard required for denationalisation. While previously the Home Secretary had to be satisfied that an individual had engaged in actions that threatened the "vital interests of the UK' state, now he or she had only to be satisfied that taking away someone's citizenship was 'conducive to the public good'. The standard for continuing

4 I discuss the normative complexities of denationalisation in Gibney, M. J. (2013), 'Should citizenship be conditional? The ethics of denationalization', The Journal of Politics 75 (3): 646-658.

5 I give a fuller account of the history of UK denaturalisation power in Gibney, M. J. (2013), “'A Very Transcendental Power”: Denaturalisation and the Liberalisation of Citizenship in the United Kingdom', Political Studies 61 (3): $637-655$. 
to hold British citizenship had now become the same as the one used to judge whether a non-citizen should be deported. Even after this radical change, it was possible to convince oneself that the government would use the power sparingly. Only a handful of people lost their citizenship under the Labour government's watch.

But with the coming of the Conservative/Liberal Democrat coalition government things have gone seriously awry. In the Cameron government's first year of office in 2010-11, no fewer than six people were stripped of their citizenship. This was more people than the Blair and Brown governments had denaturalised in the previous nine years (in the immediate aftermath of the terrorist events of September 11, 2001 and July 7, 2005). The enthusiastic use of deprivation power has continued apace in the years since, though almost always in secret. By May 2014, it was evident that Cameron's government had some 23 people stripped of citizenship on 'not conducive' grounds in the last three years. Almost all of these individuals were stripped of citizenship while outside the UK, undermining real access to appeal procedures. In January 2014 the government presented a bill to parliament requesting the power to strip citizenship from naturalised citizens even if they would be made stateless. The amendment passed, albeit, in a modified form. Under current law in the UK a naturalised citizen can be made stateless if the Home Secretary deems there are reasonable grounds for believing they have access to another citizenship.

Now it might be said - and Christian Joppke would probably be the one to say it - that the UK is an outlier. The unravelling of constraints on denationalisation evident in Britain is unlikely to be repeated elsewhere because other Western countries are less insouciant about protecting rights. But note that the circumstances that have geed along transformation in UK law are generally applicable: terrorist events (the 2005 Tube bombing) and a change of government (the coming of the Conservatives to power). Moreover, I'm not confident that other countries are as legally protected against creep of denationalisation power as they might seem. Australia has fewer rights based protections even than the UK; Canada has some alarming inclusions in its recent denationalisation legislation, including the state's ability to rely on a conviction for terrorist offences in another country; and, as I write, a large number of prominent US politicians (buoyed by public opinion polls) have effectively endorsed torture as a practice for dealing with terrorists past and future.

I thus find myself agreeing with Audrey Macklin's embrace of unconditional citizenship, albeit because I fear where we will end up if we try to pierce even a small - liberal size - hole into citizenship to punish terrorists. 
Liberalism is not simply a set of principles, it's also a political stance - one that encourages a healthy scepticism of state attempts to encroach upon established rights and protections. In these fraught times, it is wise to adopt the stance as well as to protect the principles.

Open Access This chapter is licensed under the terms of the Creative Commons Attribution 4.0 International License (http://creativecommons.org/licenses/by/4.0/), which permits use, sharing, adaptation, distribution and reproduction in any medium or format, as long as you give appropriate credit to the original author(s) and the source, provide a link to the Creative Commons license and indicate if changes were made.

The images or other third party material in this chapter are included in the chapter's Creative Commons license, unless indicated otherwise in a credit line to the material. If material is not included in the chapter's Creative Commons license and your intended use is not permitted by statutory regulation or exceeds the permitted use, you will need to obtain permission directly from the copyright holder.

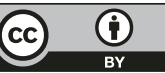

